\title{
O Desarmamento e a Paz universal
}

\author{
João Arruda
}

Os internacionalistas, que não se deixam levar por cantos de sereias, dizem a farsa do desarmamento. Com os scepticos internacionalistas está o General Denvignes, autor da monographia "La Farce du Désarmement" Com effeito, noto que difficil será, nestas conversas internacionaes, encontrar boa fé da parte dos representantes dos governos.

Tenho, por exemplo, deante dos olhos uma opinião emittida por Von PaPEN, chancheler do Reich. Seja por não estar muito bem externada a opinião do politico em francez, seja por ter elle adoptado o estylo nephelibata, tão. usado hoje pelos diplomatas desejosos de enganar seus collegas e em geral pelos amigos de desaviar o adversario, o facto é que pouco entendi das suas pretensões. Affirma que, perfilhando as opiniões de Broqueville, primeiro ministro da Belgica, entende que o mal do mundo está em falta de confiança reciproca entre a Allemanha e a França. Parece-me que quer elle dizer dever a França desarmar-se. Conseguido isto, entende o chanceler que todo o mundo se transformaria em um paraiso, e que desappareceria o pesadelo de um perigo imminente (le chauchemar d'un imaginaire danger), que leva todos os paizes a uma constante producção de metralhadoras e aeroplanos (Textual). O outro ponto por que se bate Von PAPEN é a condemnação da autarchia economica, com que os modernos significam o, 
antigo colbertismo ou auto sufficiencia economica de cada povo. É esta a causa de um vigesimo da humanidade ter falta de pão e trabalho, diz Von PAPEN, não se dando porém ao trabalho de mostrar qual a relação entre uma coisa $\mathrm{e}$ outra, ou em que o livre cambio, o arrasamento das alfandegas poderia dar serviço aos desoccupados, e pão aos famelicos: este silencio de Von PAPEN sobre tão obscuro topico de suas doutrinas faz suspeitar que o que elle teme é a concurrencia da França nos mercados estrangeiros, onde pela qualidade de seus productos vencem estes, mesmo as barreiras alfandegarias e as taxas pesadas dos paizes consumidores. Sabido é que a arma da França na concurrencia é a qualidade do producto; e a da Allemanha, o preço.

Mas deixarei o aspecto economico do que disse Von Papen, e entrarei na parte propriamente de paz universal. Ao lado do fabrico de metralhadoras e aeroplanos, ha, e não o diz Von Papen, a producção da peor das armas modernas, aquella que, mesmo sem o auxilio das armas de fogo, das peças de artilharia, de carabinas e de aeroplanos, mas só pelo uso das mãos nuas póde ser decisiva em uma guerra: refiro-me á guerra chimica e á bacteriologica. Dizem os francezes que os primeiros a empregar os gazes foram os allemães na grande guerra. Na grande guerra, sim, mas antes, já os inglezes tinham usado da lignite contra os boers. E seja dicto de passo que são elles, que, em sua ilha, vendo que estão tanto quanto qualquer outro povo sujeitos á acção dos gazes cahidos de aeroplanos, proclamam que é o gaz toxico a arma unica que deve ser condemnada na guerra. Fóra, porém, traduzir a indicação da Inglaterra um esforço pro domo, ha a impossibilidade de ser prohibida a producção de gazes toxicos. Basta considerar que são indispensaveis á industria as matérias primas com que se produzem facilmente estes venenos, para se banir das propostas viaveis a de não fabrico de gazes. Póde ser affirmado que não se comprehende um povo que não consuma o gaz de illuminação e o chloro. Pois bem! São estes os dois agentes da producção de um dos mais terriveis gazes de guerra, 
o denominado yperite. Ha o phosgeno, que se prepara misturando chloro gazoso com oxydo do carbonio, e expondo a mistura á luz, para se transformar em oxydo chlorureto de carbonio (Raymundo Henry, La Guerre des Gaz). Quem quizer saber o horror que é a acção dos gazes de combate lacrimogenos, asphyxiantes, cyanhydricos, mostarda, arsinos e explosivos ou incendiarios, deverá ler qualquer das multiplas monographias de que é rica em lingua franceza a literatura de Direito Internacional e de technica militar.

Mas, quando fosse possivel acabar-se com a industria de um paiz, com grave damno para a fortuna pública, quando fossem prohibidas as fábricas de côres, as principaes consumidoras de matéria prima propria para a producção de gazes de combate, ainda restava á perversidade humana a guerra bacteriologica de que se valeram nossos avós contra os indios no Brasil: atiravam roupas usadas por variolosos dentro das tabas ou aldeias dos selvagens. Si pois, por um movimento tolo de humanidade, para me servir da expressão do General Denvignes (La Farce du Désarmement), nós mutilarmos nossas industrias, acabarmos com o fabrico de armas de guerra, fizermos todas as tolices (Denvignes) dos patetas que acreditam no altruismo internacional, alem de ficarmos em condições inferiores mesmo ás menores potencias, nenhuma segurança poderemos dar ao mundo de nossa nenhuma efficacia bellica. Si a tudo isto puder juntar nosso povo o espirito de cobardia, sim, estará ad servitutem paratus. Emquanto porém nas veias do povo correr o sangue de gente corajosa, armas não faltarão para sua defesa. Aos bravos sempre restam armas, ainda que sejam as unhas e os dentes. Lembremo-nos do dialogo entre o marechal Zamet e seus soldados no cerco de Montpellier em 1620: "Maréchal! Nous n'avons plus ni plomb, ni poudre. - Eh! vous avez vos ongles." A paz por que todos anhelamos conseguir-se-á graças a uma propaganda nos moldes que têm sido adoptados pelos norteamericanos (educating for peace), tractando de estudar e eliminar todos os factores da guerra. Quem ler as monographias de Le Wita, Raymundo Henry, 
Ludwig Bauer, Langevin e outros militares e internacionalislistas, reconhecerá que pretender acabar com a guerra por meio do chamado desarmamento é querer endireitar a sombra da vara torta.

Si os somnambulos que pretendem desarmar o mundo, ou melhor os tolos do mundo que idearam extinguir a guerra por meio do desarmamento, nada mais fizessem, em estupido simplismo, do que prohibir a acquisição de armas no estrangeiro, e não reprimissem as industrias que podem produzir gazes, nenhum mal dahi adviria para a patria delles. Mas, si tiverem a infeliz lembrança de restringir o fabrico de armas e navios de guerra, profundo ataque soffrerá a industria nacional, sem nenhuma vantagem para a paz mundial.

É por emquanto a guerra uma fatalidade a que está sujeito o genero humano. Desde 1918, não houve no mundo um só dia de paz, a promettida paz aos que tomaram parte na grande guerra. Escreveu Ludwig BAUER uma monographia sob o titulo "La Guerre est pour demain" Que engano! A guerra é para hoje, para amanhan, e infelizmente para muitos seculos ainda, por mais esforços que façamos para a extinguir nós os pacifistas. Nada de illusões!

Uma palavra ainda insistindo sobre o que foi dicto no começo deste artigo: os gazes são facilmente lançados não só pelas armas de fogo, mas tambem pelas mãos nuas dos combatentes. A guerra chimica será empregada sempre que uma facção estiver em perigo. Lembra-me que, si não fosse o espirito summamente humano do interventor Pedro de Toledo, teriamos nós paulistas empregado os recursos chimicos de que tinhamos grande cópia, e de que (digam o que disserem) não dispunham as forças adversarias, donde grande probabilidade de victoria para São Paulo, contra o qual só empregavam os inimigos os explosivos, naturalmente. por falta de outros agentes chimicos.

O desarmamento é inefficaz para a obtenção da paz. Privados os povos dos meios de aggressão de que hoje dispõe o homem graças ao progresso das industrias, cohibido, 
si possivel, o uso dos agentes chimicos, usariam em último caso os homens de uma ponta de ferro na extremidade de uma vara de madeira como arma de lucta. Que cumpre fazer para conseguir a paz na humanidade? Parece-me que ha uma unica resposta acceitavel: investigar quaes os factores da guerra para os eliminar, quando possivel. É o caminho que têm seguido os philanthropos e sociologos norteamericanos. Dando attenção quasi exclusivamente ao nacionalismo (patriotismo mal entendido ou de campanario), factor sem dúvida importantissimo, escreveu KREHBIEL sua valiosissima monographia "Nacionalismo, Guerra e Sociedade" É tambem ao nacionalismo particularmente que ligam a maior importancia os autores da "Educação para a Paz", os esposos Lobingier. Com ser o nacionalismo um dos coefficientes principaes, não é porém o unico.

Extendendo mais a investigação, affirmou-se que, nas classes menos cultas, predomina o factor do nacionalismo, nas médias o do capital, e nas altas o do imperialismo. Antiquada é a opinião de que era o governo, o chefe de Estado que provocava as guerras: as mais das vezes isto succede apparentemente, mas antes da solemne declaração de guerra já uma classe agiu sobre o espirito do chefe supremo, ou melhor o constrangeu á declaração, á ruptura das relações pacificas. Não se póde negar que um Napoleão I guerreasse por inclinação, por indole bellicosa, mas é a rára excepção.

Quem melhor analysou os elementos causadores das guerras foi, a meu ver, Harry Elmer Barnes. Darei summarissimamente o que diz o grande sociologo norteamericano. Para elle em cinco classes podem ser dispostos estes factores: biologicos, psychologicos, sociologicos, economicos e politicos.

Nos biologicos colloca em $10^{\circ}$ logar o temor de falta de alimentos. Ainda os meios rusticos, que desconhecem por completo as theorias de Malthus, têm um vago temor, que por ser vago não deixa de ser accentuado, de que venham a faltar pão e abrigo em consequencia do desenvolvimento da concurrencia vital. 
Um 2..$^{\circ}$ factor biologico exerce influencia sinistra na sorte da humanidade, e é a tendencia bellicosa do homem. Sem dúvida, essa natureza guerreira é pouco accentuada entre os animaes gregarios dentro do grupo, mas estes luctam de grupo a grupo. A paz será obra da civilização, da cultura, da comprehensão do angelismo, ou doutrina de que na guerra só ha a perder, mesmo para o vencedor.

O $30^{\circ}$ factor biologico é mais elevado, e nem sei si bem classificado está no numero dos biologicos. É o da má applicação da lei da selecção, sustentando-se que a guerra tem o effeito de conservar os mais fortes, mais aptos para vencerem na lucta pela vida. Desenvolvendo esta doutrina, que é antiga, do tempo de Donoso Cortez, affirmam mesmo com evidente exaggero, seus partidarios que todo o progresso da humanidade tem sido devido ás guerras. Recentissimamente (Abril de 1931) ainda em Roma, foi isto sustentado em um notavel artigo na "Rivista Internazionale di Filosofia del Diritto" pg. 139, pelo professor Orestano. É a opinião dos militares allemães, que asseveram ser a lucta internacional elemento de elevação dos sentimentos do povo.

Antes de passar adeante, direi que se mostrou ter até diminuido a estatura dos francezes na $1 .^{\mathrm{a}}$ geração após as guerras de Napoleão. Faz pois a guerra uma selecção inversa, levando, como disse um sociologo, os melhores. Não são os sentimentos nobres creados pela guerra, mas se manifestam nella. Prégar estas verdades e não o anodyno ou illusorio desarmamento é que é educar para a paz.

Passo aos coefficientes psychologicos. $\mathrm{O} 10^{\circ} \mathrm{e}$ um errado culto dos heroes. Este ponto é muito delicado. Não é possivel condemnar um certo respeito áquelles que, por dever ás leis de seu paiz, morreram no campo de lucta. Escarrar no tumulo do soldado desconhecido, daquelle que cumpriu as leis de sua patria, é coisa que repugna a todos os espiritos rectos. O que se condemna é o culto constante a todos os que voluntariamente, por espirito de lucta, por 
amor ao morticinio, arrastaram os seus irmãos ás pugnas cruentas e sempre prejudiciaes ao seu paiz (angelismo).

O 2. ${ }^{\circ}$ factor psychologico é tambem de determinação muitissimo delicada: refiro-me ao patriotismo. Longe de mim censurar nos outros este sentimento natural de amor ao torrão em que nasci, e em que viveram meus antepassados. É só o exaggero do patriotismo que é condemnavel. Comprehender que não ha raças superiores, mas sim raças mais apías para taes ou taes funcções, eis em que consiste para mim a educação de respeito a todo o genero humano. Esta capacidade mesmo de raças para certas especialidades depende muito de circumstancias de logar e de accidentes historicos. Repetem os sociologos que os judeus eram agricultores, e que, pelas perseguições de que foram victimas, é que se entregaram á industria mercantil, notadamente aos negocios de dinheiro, sujeitos como se achavam a subitas expulsões.

Affirma Barnes que o desenvolvimento das communicações têm sobremodo exacerbado esta aberração do patriotismo. No seculo XVIII, diz elle, pouco sabiamos do que se passava em outros paizes, ou tarde tinhamos notícia das occurrencias internacionaes. Hoje porém o telephone, o telegrapho aereo e o por fios, a estrada de ferro, os jornaes baratos, as facilidades postaes, e outros progressos têm accentuado este sentimento commum, levando-o a uma exaltação que é peculiar somente ás multidões. Ao almoço, lê o pacifico burguez, subdito de uma grande potencia, que, em consequencia de um supposto insulto ao pavilhão de sua patria na China ou no centro da Africa, bombardeou a esquadra de seu paiz um porto do Oriente, ou o exercito colonial matou um elevado numero de selvagens: que satisfação sente o orgulho do burguez na sua primeira refeição diaria! Vem-lhe ao espirito que todos os seus patricios tiveram notícia do acto de bravura de suas forças poderosissimas e. eis o primeiro factor da loucura collectiva, esquecidos todos estes homens civilizados de que as víctimas dessas brutalidades são membros do genero humano. 
Não é menos sinistra a influencia dos estudos historicos, taes como são feitos em nossas escolas com um culto aos mais negregandos inimigos da humanidade.

O chauvinismo em França, contra o qual se insurgiram os espiritos sãos daquella nobre terra, é uma das provas deste meu asserto.

Passo agora ao estudo das causas sociologicas, como diz Barnes. São estas os conflictos de interesses, de limites territoriaes, e procura de habitats. Eu ajuntarei que até mesmo a busca da sahida para o mar pode ser um desses factores.

Passando aos economicos, que certa escola pretende serem os unicos, exaggêro inacceitavel, aponta a demanda de mercados para seus productos, de logares para collocação de capitaes, as intervenções de grandes potencias em estados fracos para protecção dos capitaes dos seus subditos (contra o que se manifestou Drago), a guerra de tarifas e a propaganda alarmista, que, não raro, toma a fórma de intriga em beneficio dos vendedores de armamentos e de outros individuos que pretendem enriquecer pela guerra.

Occupa-se emfim Barnes com os elementos politicos. Lembra que a hegemonia dos povos esteve sempre disputada: a Santa Sé, o tal imperio (successor do romano) e emfim, até data recente, as grandes potencias. Após a grande guerra, o Tratado de Versalhes, respeitando as naciona. lidades na divisão da Europa, acirrou o nacionalismo. Ef fectivamente dividir os Estados pelas nacionalidades, idea já antiga, desenvolve o patriotismo malentendido, umo aberração do amor á patria.

Concluindo, pois, direi que não é a comedia de desarmamento que poderá sopitar o espirito guerreiro, o impulso bellicoso dos povos, sentimento tão natural no homem, ou que tão profundas raizes tem no organismo humano. A educação pela paz, em que têm excellido os norteamericanos, eis o remédio unico contra o flagello da guerra.

No comeco do seculo XIX, escreveu Laboulaye sua immorredoura obra "Paris en Amérique" em que procurou 
combater certos preconceitos europeus contra os norteamericanos, cuja cultura não era bem comprehendida no Velho Continente. Mostrou que os do Novo Mundo eram profundamente humanos, caridosos e que estavam longe de ser os homens metallicos e brutaes que se figuravam os europeus sem maior exame. Este erro continúa, mesmo no Brasil, e cumpre que seja proclamado que o escol dos Estados Unidos é idealista, philanthropico, humanissimo e interessantissimo pela sorte do mundo, chegando até ao civis sum totius mundi. Traducções das innumeras obras de educação contra a guerra, escriptas em inglez, para as linguas de todos os povos cultos sería o maior beneficio que á humanidade se poderia fazer. 